\title{
SHV-type Extended-spectrum ß-lactamase (ESBL) are encoded in related plasmids from enterobacteria clinical isolates from Mexico
}

\author{
Ulises Garza-Ramos, M en C,(1) Esperanza Martínez-Romero, PhD,(2) Jesús Silva-Sánchez, PhD.(I)
}

\author{
Garza-Ramos U, Martínez-Romero E, Silva-Sánchez J. \\ SHV-type Extended-spectrum B-lactamase (ESBL) \\ are encoded in related plasmids \\ from enterobacteria clinical isolates from Mexico. \\ Salud Publica Mex 2007;49:4I5-42I.
}

\begin{abstract}
Objective: In this work we report the molecular characterization of B-lactam antibiotics resistance conferred by genes contained in plasmids from enterobacteria producing extended-spectrum ß-lactamases (ESBL). Material and Methods: Fourteen enterobacterial clinical isolates selected from a group of strains obtained from seven different hospitals in Mexico during 1990-1992 and 1996-1998 were analyzed at the Bacterial Resistance Laboratory (National Institute Public Health, Cuernavaca). Molecular characterization included PFGE, IEF of B-lactamases, bacterial conjugation, PCR amplification and DNA sequencing, plasmid extraction and restriction. Results: Isolates were genetically unrelated. ESBL identified were SHV-2 (5/I4) and SHV-5 (9//4) type. Cephalosporin-resistance was transferable in 9 of I4 (64\%) clinical isolates with only one conjugative plasmid,DNA finger printing showed a similar band pattern in plasmids. Conclusions: The dissemination of cephalosporin resistance was due to related plasmids carrying the ESBL genes.
\end{abstract}

Key words: enterobacteria, plasmid, ESBL, SHV-5, SHV-2; Mexico
Garza-Ramos U, Martínez-Romero E, Silva-Sánchez J. B-Lactamasas de espectro extendido (BLEE) tipo SHV están codificadas en plásmidos relacionados en aislamientos clínicos de enterobacterias en México. Salud Publica Mex 2007;49:4I5-42I.

\section{Resumen}

Objetivo: En este trabajo se reporta la caracterización molecular de la resistencia a antibiótico ß-lactámicos conferida por genes contenidos en plásmidos de enterobacterias productoras de ß-lactamasas de espectro extendido (BLEEs). Material y métodos: Catorce aislamientos clínicos de enterobacterias fueron seleccionados por conveniencia de un banco de cepas obtenidas de siete diferentes hospitales de México durante los periodos 1990-1992 y 1996-1998 y fueron procesados en el Laboratorio de Resistencia Bacteriana (Instituto Nacional de Salud Pública, Cuernavaca). En la caracterización se empleó PFGE, IEF para ß-lactamasas, conjugación bacteriana, amplificación por PCR y secuenciación de DNA, extracción y restricción de plásmidos. Resultados: Las 14 cepas fueron no relacionadas genéticamente. Se identificaron BLEEs tipo SHV-2 (5//4) y SHV-5 (9//4). La resistencia a cefalosporinas fue transferida por conjugación en 9 de 14 (64\%) aislamientos clínicos mediante un plásmido que mostró un patrón de restricción similar entre ellos. Conclusión: Se sugiere que la diseminación de la resistencia a cefalosporinas fue debida a plásmidos relacionados que contienen los genes que codifican BLEEs.

Palabras clave: enterobacterias, plásmido, BLEE, SHV-5, SHV-2; México

(I) Departamento de Resistencia Bacteriana, Centro de Investigaciones Sobre Enfermedades Infecciosas. Instituto Nacional de Salud Pública

(2) Centro de Ciencias Genómicas, Universidad Nacional Autónoma de México. Cuernavaca, México.

Received on: September II, 2006 - Accepted on: September 18, 2007

Address reprint requests to: Dr. Jesús Silva-Sánchez. Instituto Nacional de Salud Pública. Av. Universidad 655 col. Santa María Ahuacatitlán, 62508 Cuernavaca, Morelos, México.

E-mail:jsilva@correo.insp.mx. 
$\mathrm{T}$ here is a need to study the epidemiology of extended-spectrum ß-lactamase-producing enterobacteria (ESBL-PE) as antibiotic resistance is an increasing problem in healthcare institutions. ${ }^{1}$ Novel ESBLs gene variants have emerged. ${ }^{2,3}$ Most ESBLs are variants of the classical TEM-1 and SHV-1 B-lactamases, with one or more amino acid substitutions that confer resistance to broad-spectrum cephalosporins and aztreonam. ${ }^{3}$ These changes alter the catalytic site allowing the hydrolysis of oxyimino cephalosporins and monobactams. ${ }^{4}$ Almost all SHV coding ESBL genes have G/ A mutations, which specify glycine/serine and glutamate/lysine substitutions at amino acids 238 and 240, respectively. ${ }^{5}$ In general, the substitution at position 238 (SHV-2) confers a large increase in resistance to cefotaxime, while the additional substitution at position 240 (SHV-5) confers a large increase in resistance to ceftazidime. ${ }^{6}$ These mutations have been documented in clinical isolates of Klebsiella pneumoniae from hospitals in Mexico and have been implicated in outbreaks with high mortality. ${ }^{7-9}$ Meanwhile, 101 different SHV mutants have been recognized worldwide (http: / / www.lahey.org/Studies /).

Because the genes coding for these enzymes are located on plasmids, ${ }^{8-10}$ we wondered if some of the plasmids expressing shv -derived $_{\text {enzymes from different }}$ clinical isolates in Mexico could be related, thus we used restriction enzymes to analyze the plasmids expressing these enzymes isolated from different geographically distant hospitals over several years.

The approach that we followed was to characterize ESBL-producers by the isoelectric point of the B-lactamases, PCR analyses, sequence of the genes involved and restriction patterns of the DNA of the plasmids encoding these genes.

\section{Material and Methods}

Bacterial strains. One-hundred and fifty-seven clinical isolates of ESBL-PE causing nosocomial infections were each collected from a different patient during a six-year period (1990-1992 and 1996-1998) in seven hospitals in Mexico. Hospitals 1, 2, 3 and 6 are located in Mexico City, hospitals 5 and 7 are $70 \mathrm{~km}$ from Mexico City, and hospital 4 is $785 \mathrm{~km}$ from Mexico City (table I). All clinical isolates were identified with the API 20E system (BioMerieux, Merck. Germany) and confirmed as ESBL-producers. In order to perform further molecular characterization, 14 strains were selected to include one strain from each hospital. In cases corresponding to an outbreak or endemic clone in the hospital, the strain represents from 6 to 94 independent clinical isolates: this was the case of strains K806-4 (6 isolates), ${ }^{11}$ K910-5 (21 isolates), ${ }^{12} \mathrm{~K} 1333-2$ and K1335-2 (12 isolates), ${ }^{13} \mathrm{~K} 1509-$
6 (94 isolates) ${ }^{9}$ and C1177-7 (16 isolates) (this work) as indicated in table I. The species included were: nine of $K$. pneumoniae, two K. variicola, two E. coli, and one $E$. cloacae. Strains were named first with the first letter of the corresponding specie, followed by the number of the strain and finally number of the hospital where it was obtained.

Susceptibility testing. Bacterial antimicrobial susceptibility was initially determined with the MicroScan (Dade, Behring, USA) system using the combo 20 panel. Subsequently, MICs for cefotaxime and ceftazidime were determined by Etest strips on Mueller-Hinton agar following the recommendations of Clinical and Laboratory Standards Institute (CLSI). ESBL production was confirmed by the double disk diffusion method with cefotaxime and ceftazidime alone and in combination with clavulanic acid, interpretation criteria was as indicated in the CLSI. ${ }^{14}$

Genomic DNA typing. For pulse-field gel electrophoresis (PFGE) typing, whole cell DNA was obtained according to the method described by Kaufmann. ${ }^{15}$ DNA was digested with XbaI (Gibco, BRL, UK.) and separated in 2\% agarose gels (Pulsed Field-Certified; Pronadisa, Madrid) with a Gene-Path System (Bio-Rad, Hercules, USA). Gels were stained with ethidium bromide and analysed according to the criteria of Tenover et al. ${ }^{16}$

Plasmid profile and mating experiments. Plasmid DNA was extracted from clinical isolates and the respective transconjugant according to the method described by Kieser. ${ }^{17}$ DNA was visualized after vertical electrophoresis in $0.7 \%$ agarose gels stained with ethidium bromide. Plasmids R6K (40 kb), RP4 (54 kb), R1 (205 $\mathrm{kb})$ and pUA21 $(300 \mathrm{~kb})$ were used as molecular weight markers. Matings were performed on filters placed on solid LB-Luria medium according to Miller, ${ }^{18}$ using Escherichia coli J53-2 (F-, pro, met, Rif ${ }^{\mathrm{r}}$ ) as the receptor strain. In all cases, transconjugants were selected on Luria agar supplemented with rifampin $(100 \mu \mathrm{g} / \mathrm{ml})$ in combination with cefotaxime $(1 \mu \mathrm{g} / \mathrm{ml})$, or ampicillin $(50 \mu \mathrm{g} / \mathrm{ml})$. Transconjugants were denoted with an $X$ after the donor strain designation.

IEF of $\beta$-lactamases and bioassay. Crude cell protein preparations from clinical isolates and transconjugants were obtained from sonicated extracts prepared in 0.05M phosphate buffer ( $\mathrm{pH} 7.0$ ). Crude extracts were subjected to isoelectric focusing (IEF) by the procedure described previously, ${ }^{19}$ using a Phast system minigel with a $\mathrm{pH}$ range from 3 to 9 (Amersham, Biosciences, UK). Following IEF, ß-lactamase bands were visualized with nitrocefin (Oxoid, Hampshire, UK). After IEF, the cefotaxidimase activities of separated B-lactamases were detected by the bioassay described previously. ${ }^{20}$ Extracts from TEM-1, SHV-1 and SHV-5-producing 
Table I

\section{EPIDEMIOLOGY AND MOLECULAR CHARACTERISTICS OF THE ENTEROBACTERIACEAE}

\begin{tabular}{|c|c|c|c|c|c|c|c|c|c|c|c|}
\hline \multirow[b]{2}{*}{ Strain } & \multirow[b]{2}{*}{ Species } & \multirow[b]{2}{*}{ Hospitals } & \multirow[b]{2}{*}{$\begin{array}{l}\text { Year of } \\
\text { isolation }\end{array}$} & \multirow{2}{*}{\multicolumn{2}{|c|}{$\begin{array}{c}\text { MIC** } \\
(\mu g / \mathrm{ml})\end{array}$}} & \multirow{2}{*}{$\begin{array}{c}\text { Plasmid } \\
\text { profile } \\
\text { (Kb) }\end{array}$} & \multirow[b]{2}{*}{$\begin{array}{l}\text { Plasmid } \\
\text { Pattern }\end{array}$} & \multicolumn{3}{|c|}{ B-lactamase(s) } & \multirow[b]{2}{*}{ Reference } \\
\hline & & & & & & & & $\begin{array}{c}p l \\
\text { value }^{2}\end{array}$ & $\begin{array}{l}\text { bla } \\
P C E M\end{array}$ & $\begin{array}{l}\text { blagene } \\
\text { content } t^{*}\end{array}$ & \\
\hline K55-I & K. pneumoniae & I & 1990 & 16 & 32 & $235, \underline{150}$ & IV & (7.6) & - & SHV-2 & This work \\
\hline K65-I & K. pneumoniae & I & 1990 & 128 & 64 & $\underline{280}, 80$ & III & $5.4,(7.6), 8.1$ & + & SHV-2 & This work \\
\hline E86-2 & E. coli & 2 & 1990 & 32 & 64 & $\underline{260}, 120$ & III & $5.4,7.4,(8.2)$ & + & SHV-5 & This work \\
\hline K96-I & K. pneumoniae & I & 1990 & 8 & 2 & $270,250,215,195$ & I & $\underline{5.4,(7.6)}$ & + & SHV-2 & This work \\
\hline K97-2 & K. pneumoniae & 2 & 1991 & 2 & 4 & $\underline{270}, 250,215,195$ & $\mathrm{I}$ & (8.2) & - & SHV-5 & This work \\
\hline $\mathrm{K} 102-2$ & K. pneumoniae & 2 & 1991 & 4 & 32 & $\underline{275}, 240$ & II & $5.4,(8.2)$ & + & SHV-5 & This work \\
\hline EI28-3 & E. coli & 3 & 1992 & 8 & 8 & $\underline{290}, 240,150$ & II & $\underline{5.4,(7.6)}$ & + & SHV-2 & This work \\
\hline $\mathrm{K} 806-4^{\infty}$ & K. variicola & 4 & 1996 & 8 & 1 & $275, \underline{185}$ & ND & $\underline{5.4,(7.6)}$ & + & SHV-2 & This work \\
\hline $\mathrm{K} 910-5^{\circ}$ & K. pneumoniae & 5 & 1996 & 32 & 256 & 159,40 & ND & $5.4,7.6,(8.2)$ & + & SHV-I/SHV-5 & 12 \\
\hline $\mathrm{KI} 333-2$ & K. pneumoniae & 2 & 1996 & 8 & 64 & 255,135 & ND & $5.4,7.6,(8.2)$ & + & SHV-I/SHV-5 & 13 \\
\hline $\mathrm{K} 1335-2^{\circ}$ & K. pneumoniae & 2 & 1996 & 64 & 256 & 255 & ND & $5.4,7.6,(8.2)$ & + & SHV-I/SHV-5 & 13 \\
\hline $\mathrm{K}|3| 9-2$ & K. variicola & 2 & 1997 & 8 & 256 & 255,135 & ND & $5.4,7.6,(8.2)$ & + & SHV-I/SHV-5 & This work \\
\hline $\mathrm{K} 1509-6^{\circ}$ & K. pneumoniae & 6 & 1997 & 2 & 16 & 305 & ND & $5.4,(8.2)$ & + & SHV-5 & 9 \\
\hline$\overline{C I I 77-7^{\circ}}$ & E. cloacae & 7 & 1998 & 16 & 256 & $255,206, \underline{70}$ & V & $5.4,7.6,(8.2)$ & + & SHV-5 & This work \\
\hline
\end{tabular}

Experimental data was done at the Instituto Nacional de Salud Pública from 2003 to 2004 period.

* MIC: Minimum Inhibitory Concentration; CTX: cefotaxime; CAZ: ceftazidime

₹ The underlined plasmids are the transferred plasmids in the conjugation

§ I) Instituto Nacional de Ciencias Médicas y Nutrición Salvador Zubiran;2) Hospital Infantil de México;3) Hospital de Infectología CMN “La Raza”;4) Hospital del Niño de Tabasco; 5) Hospital Civil de Cuernavaca; 6) Hospital de Pediatría CMN, IMSS; 7) Hospital del Niño Morelense

\# The pattern plasmids determinate according to the correlation coefficient. ND; not determined

\& pl: Isoelectric point of B-lactamase in parenthesis corresponds to ESBL. Underlined pls are the B-lactamases encoded in transconjugant

* bla $a_{\text {SHV }}$ determined by DNA sequence

${ }^{\infty}$ Clinical isolates corresponding to outbreak or endemic clones

strains were used as the standards for pIs of 5.4, 7.6 and 8.2 , respectively.

TEM and SHV-specific PCR and DNA sequencing. The oligonucleotide primers OT1 and OT2 which amplify a region of TEM genes were used..$^{21}$ Only ESBL genes were considered for further molecular characterization using the DNA from some ESBL strains and resulting transconjugants. To amplify SHV-related genes the oligonucleotide primers SE5 and SB3 were used for PCR amplification as described by Silva et al. ${ }^{12}$ Reactions were carried out in a $50 \mu$ l volume containing 1 X PCR amplification buffer, 3 X Enhancer buffer (PCRX Enhancer System; Gibco, BRL, USA), amplification conditions were: $5 \mathrm{~min}$ of denaturation at $94^{\circ} \mathrm{C}$; 30 cycles of $30 \mathrm{sec}$ at $94^{\circ} \mathrm{C}, 30 \mathrm{sec}$ at $58^{\circ} \mathrm{C}$ and $2 \mathrm{~min}$ at $72^{\circ} \mathrm{C}$; and a final extension for $15 \mathrm{~min}$ at $72^{\circ} \mathrm{C}$. The resulting PCR products were analysed in 1.5\% agarose gels; samples producing one sharp band were purified with a column kit (High Pure ${ }^{\mathrm{TM}}$ PCR Purification Kit, Boheringer, USA) and used for sequencing reactions with the dideoxy chain termination using an automatic sequencer (ABI PRISM
377-18, kit EL:Taq FS Dye Terminator Cycle Sequencing Fluorescence-Based Sequencing). Primers SEC5' (5'-TCAGGAGGTTGACTATGCGT-3') (this study) and P1 (5'-ATCGAATGAGGCGCTTCC-3'), ${ }^{22}$ were used for sequencing the amplified PCR products.

Sequence Analysis. Amino acid sequences were obtained using Translate tool, available at ExPASy (http:/ / www. expasy.ch/tools/dna. html). Multiple-alignment of nucleotide and amino acid sequences was done with ClustalW (http: / / clustalw.genome.jp/) and compared with the SHV-1 gene (GENBANK Accession number AF148850).

Plasmid DNA fingerprinting. Plasmid DNA purification from transconjugants was performed with QIAGEN Plasmid Midi Kit (QIAGEN, Hilden, Germany) ionic interchange columns, according to the manufacturer's procedure. Fingerprinting analysis was performed with DraI restriction enzyme (Promega. USA and Gibco, BRL, USA). The resulting DNA fragments were analysed in $2 \%$ agarose gels. The dendrogram of DraI restriction pattern was achieved using the NTSYSpc 2.0 program. 


\section{Results}

Clinical isolates and susceptibility test. Isolation dates spanned a period of six years, from 1990 to 1992 and 1996 to 1998, collected from seven hospitals and three different cities in Mexico. General characteristics of all 14 clinical isolates are described in table I. All strains were susceptible to cefoxitin, imipenem and ciprofloxacine, they were confirmed as ESBL producers by the double disc method. In general the MICs for ceftazidime and cefotaxime were heterogeneous. Five of these clinical isolates represent outbreaks or endemic clones at each hospital, some of them reported previously: K806-4, K910-5, K1332-2, K1335-2, K1509-6 and C1177-7, representing 6, 21, 12, 94 and 16 endemic clones, respectively (see methods and table).

Typing by genomic DNA PFGE analysis. In this work, PFGE genomic DNA analysis from each species group was carried out with the nine clinical isolates of $K$. pneumoniae, two K. variicola and two E. coli. The XbaI restriction profiles showed different DNA patterns between these three groups (data not shown), indicating no genetic relation within the species.

Plasmid profile and mating experiments. The 14 clinical isolates harboured 1-4 plasmids with sizes of 40-290 kb. To define if the resistance genes were plasmid borne, bacterial conjugation was performed and resistant recipients were selected. Only 9 of 14 clinical isolates were capable of transferring the resistance to the susceptible E. coli J53-2 strain, and corresponded to five of the nine K. pneumoniae clinical isolates tested, one of the two $K$. variicola tested, the two E. coli and the E. cloacae clinical isolates included in this study. In all cases the transconjugants received one plasmid originally contained in the respective isolate; these plasmids are underlined in table I.

$\beta$-Lactamase profiles and detection of ESBL. All 14 clinical isolates expressed 1 to 3 B-lactamases with different isoelectric points (pI). Three main bands were identified with pI's of 5.4, 7.6 and 8.2. In addition to these bands, two more bands were detected with pI's of 7.4 (strain E86-2) and 8.1 (strain K65-1), (table I). The B-lactamase with pI 5.4 was identified in 12/14 isolates, and the enzyme with pI 7.6 was expressed in 10/14 isolates. The $\beta$-lactamase with pI 8.2 was present in 9/14 strains. In order to identify the ESBL encoded in each clinical isolate and the respective transconjugant, the bioassay (as mentioned in Material and Methods) was performed on the IEF gels. Two bands (one from each clinical isolate and transconjugant) were detected as ESBL. The enzyme with pI 7.6 was identified in 5/14 clinical isolates and was obtained from three K. pneumoniae, one K. variicola, and one E. coli. The ESBL with pI 8.2 was detected in
9/14 clinical isolates which included six K. pneumoniae, one K. variicola, one E. coli, and one E. cloacae. Five of these strains produced an enzyme with $\mathrm{pI} 7.6$ with no cefotaximase activity (non-ESBL). Considering the B-lactamase profile and the ESBL encoded in transconjugants, two major groups (including four strains each) were identified with pI 5.4, 7.6; and 5.4, 8.2. Data corresponding to transconjugants are underlined indicated in table. The detection of TEM-encoding ß-lactamase by PCR amplification for $b l a_{\text {TEM }}$ allele was carried out with all clinical isolates. A fragment of 503-pb was obtained in 12 of 14 bacterial strains and corresponded to the isolates that expressed the 8 -lactamase with $\mathrm{pI}$ 5.4, which does not have cefotaximase activity in the bioassay and does not correspond to an ESBL (table I).

Identification of SHV-type ESBL by PCR amplification and sequencing. Only ESBL genes were considered for the molecular characterization, according to the $\mathrm{pI}$ values (7.6 and 8.2) these enzymes could correspond to SHVderived ESBL. PCR amplification of SHV genes was performed with 14 isolates; all of them produced a DNA fragment corresponding to the expected size of $0.9 \mathrm{~kb}$ (representing the complete $b l a_{\mathrm{SHV}}$ gene and the signal peptide region). In order to identify mutations in this gene, the 14 PCR products obtained were sequenced and the deduced amino acid sequence compared with the wild type SHV-1 enzyme. ${ }^{23}$ In five cases, a Gli238Ser (G697A) substitution was detected indicating the presence of the previously described SHV$2 .{ }^{25}$ Nine clinical isolates showed Gli238Ser (G697A) and Glu240Lys (G680/A) substitutions, which corresponded to SHV-5. ${ }^{25}$ (table I). Amplicons from clinical isolates K910-5, K1333-2, K1335-2 and K1319-2 yielded sequences with clear double G/A peak nucleotides at the first position of codons 238 and 240. In addition to this mutation, the PCR sequence of strain K1335-2 included a double peak nucleotide at the third position of codon 240. The double nucleotide peak at the first position of codon 238 corresponded to adenine $(A)$ and guanine $(G)$ nucleotides, corresponding to serine ( $\underline{\mathrm{AGC}}$ ) and glycine (GGC) codons, respectively. A similar case was identified at the first and third positions of codon 240 in strain K1335-2, where the base combinations corresponded to glutamic acid ( $\underline{\mathrm{G}} \mathrm{A} \underline{\mathrm{G}}, \underline{\mathrm{G}} \mathrm{A} \underline{\mathrm{A}})$ and lysine ( $\underline{\mathrm{A}} \underline{\mathrm{G}}, \underline{\mathrm{A}} \mathrm{A} \underline{\mathrm{A}})$ codons. These results suggest the amplification of a mixture of PCR products, one of them corresponding to SHV-1 (non ESBL) and the other to SHV-5 (ESBL). Plasmid profile. With the goal of identifying similar DNA regions in the conjugative plasmids expressing SHVderived ESBL, the plasmidic DNA from transconjugants (which contain only one plasmid) was digested with DraI enzyme. The restriction pattern showed at least three common bands in all plasmids with sizes of $6.5,2.1$ 
and $1.0 \mathrm{~kb}$ (figure 1), with additional bands shared between several plasmids. Interestingly, the plasmid from the transconjugants of clinical isolates K96-1 and K97-2 had identical DNA restriction pattern, even though they were collected during different years (1990 and 1991, respectively) and hospitals settings (figure 1 , slots 4 and 5). The dendrogram generated with the DraI restriction pattern of conjugative plasmids showed three main groups of plasmids excluding the XK55-1 and XC1177-7 strains; in general the correlation coefficient was up to 0.55 (figure 2). Group I included XK96-1 and XK97-2, group II included XK102-2 and XE128-3 and group III included XK65-1 and XE86-2 transconjugants.

\section{Discussion}

The present study includes the molecular characterization of cephalosporin resistance in 14 clinical isolates of ESBL-EP (including endemic clones from different hospitals) and the respective plasmids patterns encoding the SHV-derived enzyme. The ESBL identified in all clinical isolates analysed were SHV-2 and SHV-5. There was a relatedness of plasmids coding these

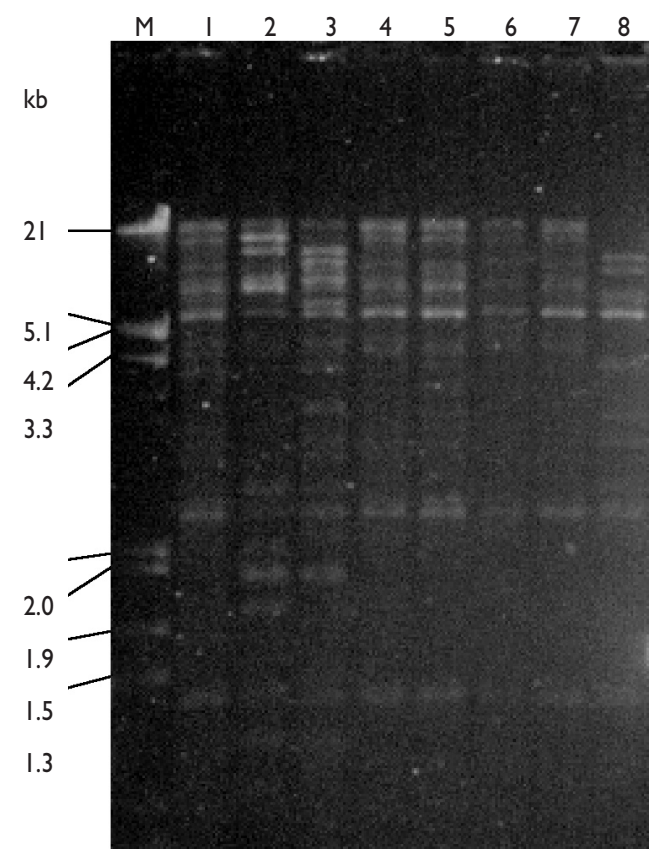

Figure I. Plasmid fingerprinting obtained with Dral DigESTION. M; DNA MOLECULAR WEIGHT MARKER, $\lambda$ E $/ \mathrm{H}^{\circ} \mathrm{I}$, XK55-I; 2, XK65-I; 3, XE86-2; 4, XK96-I; 5, XK97-2; 6, XKI02-2; 7, XEI28-3; 8, XCII77-7

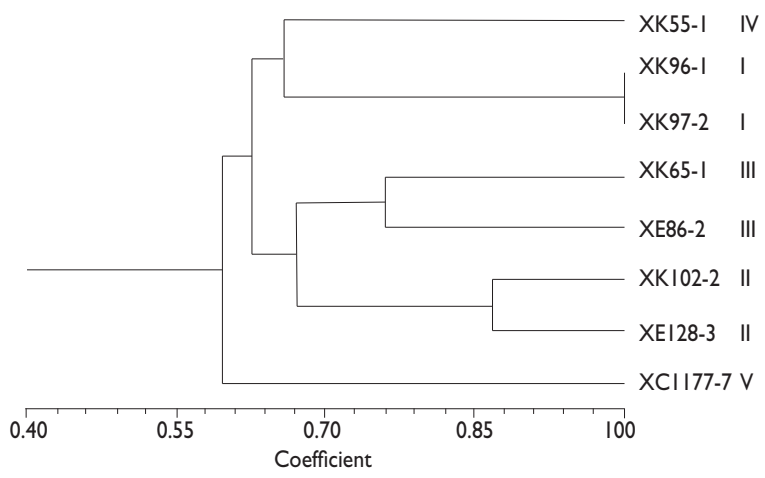

Figure 2. DendRogram of PLASMid PATTERNS ObTAINED by DNA DIgESTION WITH DRAl ENZYME

enzymes from isolates collected during six years from seven different hospitals and three different locations in Mexico.

Three groups were identified according to the results of IEF, sequence analysis of PCR product and mating experiments: Group 1: Transconjugants XK55-1, XK65-1, XK96-1 XE128-3 and XK806-44 contained only one plasmid from the clinical isolate, they expressed the SHV-2 ESBL with a pI of 7.6; Group 2: Transconjugants XE86-2, XK97-2, XK102-2 and XC1177-7 harbour only one plasmid, they expressed the SHV-5 ESBL with a pI of 8.2; Finally, Group 3: The clinical isolates K910-5, K1319-2, K1333-2, K1335-2 and K1509-6 that did not have the ability to transfer the resistance by conjugation and they expressed the SHV-5 ESBL with $\mathrm{pI} 8.2$ and SHV-1 not ESBL with pI 7.6. The interpretation of these results was based on the sequence analysis of the PCR products including double $\mathrm{C} / \mathrm{A}$ peaks at the first position of codons 238 and 240, indicating a mixture of PCR products. These amino acid combinations suggested that one enzyme corresponded to SHV-1 (glycine 238, glutamic acid 240) with a pI of 7.6, and the second to the SHV-5 (serine 238, lysine 240) with pI of 8.2. These possible combinations of amino acids are deduced based on the fact that a mutant of SHV including only the lysine at position 240 has not been previously reported (http:/ / www.lahey.org/Studies/). Similar results have been described in 13 ESBL-producer strains, in which at least four of them carried $b l a_{\mathrm{SHV}-11}$ (non-ESBL) genes in addition to the $b l a_{\mathrm{SHV}-2 \mathrm{a}}$ or $b l a_{\mathrm{SHV}-2}(\mathrm{ESBLs}){ }^{26}$

It is known that the $b l a_{\mathrm{SHV}-1}$ gene has a chromosomal K. pneumoniae origin, ${ }^{27}$ this observation must be in the clinical isolates of third group. Interestingly, the gene coding for the plasmidic SHV-5 enzyme was located on a compound transposon which originated from 
the K. pneumoniae chromosome. ${ }^{10}$ Coexistence of two different ß-lactamases of SHV (SHV-11 and SHV-2a, or SHV-11 and SHV-12) in the same clinical isolate has been reported previously. ${ }^{26}$

The horizontal transfer of a plasmid carrying ESBL SHV genes between non-related strains has been reported. ${ }^{28}$ Also, the clonal and horizontal spread of $\mathrm{SHV}$ genes in clinical isolates of K. pneumoniae has been documented. ${ }^{9}$ In general, transconjugants harboured the conjugative plasmid corresponded to the largest one, with exception of XK55-1 and XC1177-7. Five clinical isolates (K910-5, K1319-2, K1333-2, K1335-2 and K1509-6) did not have the ability to transfer the resistance by conjugation under the conditions tested; however, the K1333-2 and K1319-2 isolates belong to different species which were collected in different years with identical number and size plasmids and ESBLs.

According to the plasmid restriction pattern from transconjugants, group I have identical restriction profile but encode differentSHV-type ESBL: this group included K96-1 and K97-2 isolates which were collected in different years and hospitals. This pattern had a correlation coefficient of $>0.55$ with the plasmid pattern IV that represents the plasmid from isolate K55-1 collected in the same hospital and year as isolate K96-1, both plasmids encode SHV-2 ESBL. Plasmid pattern II includes the K102-2 and E128-3 isolates that corresponded to two different species and encode SHV-5 and SHV-2 enzymes respectively, these isolates were collected in different hospitals. This situation is similar to isolates included in plasmid pattern III (K65-1 and E86-2 isolates), both groups have a high similarity $(>0.65$ correlation coefficient). In general there is relatedness between plasmids encoding differentSHV-type ESBLs. This situation could be explained first as plasmids are promiscuous mobile genetic elements and can be transferred horizontally within different enterobacterial species. ${ }^{29}$ Secondly, one mutation distinguishes SHV-2 from SHV-5 enzymes (E240K), this mutation could occur in an independent event from SHV-2 and selected by the antibiotic exposure converting the enzyme to SHV-5., ${ }^{4,30}$ The dissemination of cephalosporin resistance among nosocomial enterobacteria strains in different hospitals in Mexico, suggests that it could be due to horizontal plasmid transmission among clonally unrelated strains (PFGE).

This situation highlights the need to establish a study for molecular epidemiology of ESBLs and plasmids harboured in this kind of clinical isolates. We hope that this study will contribute to a more complete understanding of the spread and evolution of the SHV genes in hospital settings.

\section{Acknowledgments}

This work was supported by grants 30938 and SALUD 2003-C01-009 from CONACyT. Ulises Garza-Ramos was a fellow from CONACyT. We thank Bertha Carrillo and Teresa Rojas for excellent technical assistance. Authors want to thank Dr. Jose Sifuentes (INCMNSZ), Dra. Luz Elena Espinosa de los Monteros (HIM), Dr. Rodolfo Gatica (HCC), Q. Eduardo Escamilla (HNT), Dra. Guadalupe Miranda y Dr. Fortino Solórzano (HP CMN, IMSS), MC Veronica Andrade (HNM), for providing the clinical isolates for this study, also to Dr. Michael Dunn (Centro de Ciencias Genómicas, UNAM), Cuernavaca, Morelos, Mexico, for reviewing the manuscript.

\section{References}

I. Burwen D, Banerjee, S, Gaynes R. Ceftazidime resistance among selected nosocomial gram-negative bacilli in the United States. National Nosocomial Infections Surveillance System. J Infect Dis 1994; 170:16221625.

2. Bradford P. Extended-spectrum B-lactamases in the 2 I st century: characterization, epidemiology, and detection of this important resistance threat. Clin Microbiol Rev 200I; I4:933-95I.

3. Bush K, Jacoby G, Medeiros A.A functional classification scheme for B-lactamases and its correlation with molecular structure. Antimicrob Agents Chemother 1995; 39:1211-1233.

4. Tzouvelekis L S, Bonomo R A. SHV-type $\beta$-lactamases. Curr Pharm Des 1999;5:847-864.

5. Howard C, van Daal A, Kelly G, Schooneveldt J, Nimmo G, Giffard P. Identification and minisequencing-based discrimination of SHV Blactamases in nosocomial infection-associated Klebsiella pneumoniae in Brisbane,Australia. Antimicrob Agents Chemother 2002; 46:659-664. 6. Du Bois S K, Marriott M S and Amyes S G B.TEM-and SHV-derived extended-spectrum $\beta$-lactamases: relationship between selection, structure and function. J.Antimicrob. Chemother 1995; 35:7-22. 7. Martinez-Aguilar G,Alpuche-Aranda C,Anaya C et al. Outbreak of nosocomial sepsis and pneumonia in a newborn intensive care unit by multiresistant extended-spectrum B-lactamase-producing Klebsiella pneumoniae: high impact on mortality. Infect Control Hosp Epidemiol 200I; 22:725-728.

8.Alcantar-Curiel, D, Tinoco J, Gayosso C, Carlos A et al. Nosocomial bacteremia and urinary tract infections caused by extended-spectrum B-lactamase producing Klebsiella pneumoniae with plasmids carrying both SHV-5 and TLA-I genes. Clin Infect Dis 2004; 38: I067-I074.

9. Miranda, G, Castro N, Leaños B et al. Clonal and Horizontal Dissemination of Klebsiella pneumoniae Expressing SHV-5 extendedspectrum ß-lactamase in a Mexican pediatric hospital. J Clin Microbiol 2004; 42:30-35.

10. Preston K,Venezia R, Stellrecht K. The SHV-5 extended-spectrum B-lactamase gene of $\mathrm{PACMI}$ is located on the remnant of a compound transposon. Plasmid 2004; $51: 48-53$.

I I. Rosenblueth M, Martinez L, Silva J, Martinez-Romero E. Klebsiella variicola, a novel species with clinical and plant-associated isolates. Syst Appl Microbiol 2004; 27:27-35. 
12. Silva J, Gatica R, Aguilar C et al. Outbreak of infection with extendedspectrum $\beta$-lactamase-producing Klebsiella pneumoniae in a Mexican hospital.J Clin Microbiol 200I; 39:3193-3196.

13.Andrade V, Silva-Sánchez J, Grupo de Resistencia Bacteriana. Caracterización de Klebsiella pneumoniae productora de la B-lactamasa SHV-5 en una unidad de cuidados intensivos. Salud Publica Mex 2004;46:524-528.

14. Clinical Laboratory Standards Institute. Methods for dilution antimicrobial susceptibility tests for bacteria that grow aerobically. Approved standard MI00-SI4. Clinical Laboratory Standards Institute, Wayne, Pa. 2005: 35.

15. Kaufmann ME. Methods Mol Med I5, 17-3I 1998.

16. Tenover F,Arbeit R, Goering $\vee$ et al. Interpreting chomosomal DNA restriction patterns produced by pulsed-field gel electrophoresis: criteria for bacterial strain typing.J Clin Microbiol 1995; 33:2233-2239. 17. Kieser T. Factors affecting the isolation of CCC DNA from Streptomyces lividans and Escherichia coli. Plasmid 1984; 12:19-36. 18. Miller J. Experiments in molecular genetics. New York, NY: Cold Spring Harbour Laboratory Press 1972:82-85.

19. Matthew M, Harris A, Marshall M, Ross G. The use of analytical isoelectric focusing for detection and identification of B-lactamases.J Gen Microbiol 1975; 88:169-178.

20. Silva J,Aguilar C. B-lactamase Bioassay: A simplified method to determine extended-spectrum B-lactamases (ESBL) in enterobacteria. Arch Med Res 1997; 28:285-287.

21.Arlet $\mathrm{G}$, Philippon A. Construction by polymerase chain reaction and use of intragenic DNA probes for three main types of transferable Blactamases (TEM, SHV, CARB). FEMS Microbiol Lett 1991; 66: 19-25. 22. Prodinger,W, Fille M, Bauernfeind $A$ et al. Molecular epidemiology of Klebsiella pneumoniae producing SHV-5 $\beta$-lactamase: parallel outbreaks due to multiple plasmid transfer. J Clin Microbiol 1996; 34:564-68.
23. Barthelemy M, Peduzzi J, Labia R. Complete amino acid sequence of p453-plasmid-mediated PIT-2 $\beta$-lactamase (SHV-I). Biochem J 1988; 251:73-79.

24. Bradford P.Automated thermal cycling is superior to traditional methods for nucleotide sequencing of blaSHV genes. Antimicrob Agents Chemother 1999; 43:2960-2963.

25. Billot-Klein D, Gutmann L, Collatz E. Nucleotide sequence of the SHV5 B-lactamase gene of a Klebsiella pneumoniae plasmid.Antimicrob Agents Chemother 1990; 34:2439-244I.

26. Essack S, Hall L, Pillay D, McFadyen M, Livermore D. Complexity and diversity of Klebsiella pneumoniae strains with extended-spectrum B-lactamases isolated in 1994 and 1996 at a teaching hospital in Durban, South Africa. Antimicrob Agents Chemother 200 ; 45:88-95.

27. Chaves J, Ladona M, Segura, Coira C, Reig R,Ampurdanés C. SHV-I B-lactamase is mainly achromosomally encoded species-specific enzyme in Klebsiella pneumoniae. Antimicrob.Agents Chemother 200I; 45:2856-286I. 28. Gniadkowski M, Paucha A, Grzesiowski P, Hryniewicz W. Outbreak of ceftazidime-resistant Klebsiella pneumoniae in a pediatric hospital in Warsaw, Poland: Clonal Spread of the TEM-47 Extended-Spectrum betalactamase (ESBL)-producing strain and transfer of a plasmid carrying the SHV-5-like ESBL-encoding gene. Antimicrob Agents Chemother 1998; 42:3079-3085.

29. Sorensen S, Bailey M, Hansen L et al. Studying plasmid horizontal transfer in situ: a critical review. Nat Rev Micro 2005; 3:700-7I0.

30. Ford P, Avison M. Evolutionary mapping of the SHV $\beta$-lactamase and evidence for two separate IS26-dependent blaSHV mobilization events from the Klebsiella pneumoniae chromosome. J Antimicrob Chemother 2004; 54:69-75. 